\title{
CLINICAL PRESENTATION, DIAGNOSIS AND TREATMENT OF PULMONARY FUNGUS BALL RELATED TUBERCULOSIS
}

\author{
Fenty Anggrainy ${ }^{1}$, Irvan Medison ${ }^{2}$, Deddy Herman ${ }^{1}$, Sabrina Ermayanti ${ }^{1}$, Yessy Susanty Sabri ${ }^{1}$
}

\begin{abstract}
Abstrak
Fungus Ball paru merupakan komplikasi yang sering terjadi pada Tuberkulosis (TB) paru dengan kavitas, terutama pada bekas TB paru. Agen penyebab selain Aspergilus sp yaitu Candida sp. Terapi definitif untuk penyakit ini adalah terapi bedah. Pada kondisi khusus dapat digunakan tatalaksana lainnya. Penelitian ini mengevaluasi 6 pasien Fungus Ball paru dengan riwayat obat anti tuberkulosis, dengan beberapa metode diagnosis dari tahun 2010 sampai 2013. Tatalaksana dan hasil pengobatan pasien dianalisis pada penelitian ini. Hemoptisis terdapat pada seluruh pasien dan tiga diantaranya dengan hemoptisis masif. Semua pasien memiliki gambaran yang khas untuk Fungus Ball paru dari radiologi toraks. Spesies jamur terkonfirmasi pada 5 pasien: pemeriksaan serologis (1), kultur jamur (2) dan pemeriksaan histopatologi (2). Spesies yang didapatkan adalah Aspergilosis $s p=3$, Candida paraspilosis $=1$ dan Candida $\mathrm{sp}=1$. Dua pasien mendapatkan terapi bedah dengan tidak adanya keluhan hemoptisis setelah itu. Empat pasien yang hanya mendapatkan anti jamur, ternyata $75 \%$ memberikan respon yang baik secara klinis dan radiologis. Kavitas yang menetap pada TB paru dan bekas TB paru, dapat menimbulkan insiden Fungus Ball paru yang membutuhkan lobektomi sebagai terapi definitif. Pada kondisi tertentu dimana terapi pembedahan tidak dapat dilakukan, anti jamur dapat menjadi terapi alternatif dan memberikan hasil yang baik.
\end{abstract}

Kata kunci: fungus ball paru, tuberkulosis, terapi pembedahan , anti jamur

\begin{abstract}
Pulmonary fungus ball is common complication from pulmonary tuberculosis with cavity, especially from sequele pulmonary tuberculosis. Etiologic agents not only Aspergilus sp but also Candida sp. Definitive treatment is surgical therapy. In special condition we can choose another treatment. We evaluated six pulmonary fungus ball patients with history of antituberculosis drugs, in several method of diagnosis from 2010 sampai 2013. We analyze the therapy and outcome from the patients. Hemoptysis presented in all patients and three of them got massive hemoptysis. All patients had specific appearance of pulmonary fungus ball radiologically. Fungus species confirmed in five patients: serologic examination (1), fungal culture (2), and histopathological examination (2). The species are Aspergilosis $s p=3$, Candida parapsilosis $=1$ and Candida $s p=1$. Two of them got surgical therapy and there is no more complaint of hemoptysis. Those four who took anti fungal only, so three of them (75\%) good responsive both clinically and radiologically. Preexisting cavity in pulmonary tuberculosis and former pulmonary tuberculosis, renounce the incident of pulmonary fungus ball which need lobectomy as definitive treatment. In condition where they can't perform surgical treatment, antifungal can be alternative treatment and gave good outcome.
\end{abstract}

Keywords: Pulmonary Fungus ball, Tuberculosis, Surgical treatment, Antifungal

Affiliation: 1. Department of Pulmonology Faculty of Medicine Universitas Andalas, 2. Department of Pulmonology RSUP M. Djamil Padang Correspondenc: Fenty Anggrainy, email: fentyanggrainy@med.unand.ac.id

\section{INTRODUCTION}

Preexisting lung cavity that caused by variety underlying lung disease, could be colonized by sacrophytic fungi such as Aspergillus (most common), Candida, Nocardia, Sporothrix and Peniccilium resulted fungus ball. ${ }^{1,2}$ Most of thesecavity were 
related with tuberculosis $(60 \%)$. Conglomeration of necrotic debris within the lung cavity and saprophytic growth on the lung surface occurs after inhalation of spores into the moist, warm, dark, aerated and proteinrich environment of the lung. Accumulation of layers of fungus, cellular debris, fibrin and inflammatory cells from a mobile, compact mass that may fill the cavity. ${ }^{1,3}$ The common clinical presentation is some combination of cough, expectoration, hemoptysis, chest pain, wheezing and night sweats. But the most common symptom is hemoptysis $(50-90 \%)$, could be bloodtinged sputum or massive. ${ }^{1,3,4}$ Bleeding has been attributed to mechanical friction between the mobile fungus ball and the hypervascular cavity wall, to endotoxins liberated from the fungus ball, or to type III inflammatory reaction within the cavity wall. ${ }^{2}$

The classical plain chest radiograph and thoraxic CT scanning features of a pulmonary fungus ball is characterized by the presence of a solid, round or oval mass with soft-tissue opacity within a lung cavity. Typically, the mass is separated from the wall of the cavity by an airspace of variable size and shape, resulting in the "air crescent" sign., ${ }^{1,2,4}$ The common sites of pulmonary fungus ball are the upper lobe and lower lobe superior segment. ${ }^{5}$

The causes of pulmonary fungus ball can be detected by microscopic, culture, serologic, PCR examination and histopathological examination. ${ }^{4}$ The specimen can be from sputum, bronchoalveolar lavage (BAL), brush from bronchoscopy. The selection of method and sampling based on examiner and the available facility on the hospital. ${ }^{6}$

Eventhough surgical resection is the definitive treatment for pulmonary fungus ball 7 , the best treatment for patients who are ineligible for surgery remains unknown. ${ }^{4}$ Patients with recurrent hemoptysis or massive hemoptysis, surgery is performed with considering the complication of surgery which mainly depend on pulmonary function and general condition. It is considered for embolization or anti fungal medication intracavitary if surgery cannot perform. ${ }^{1,2,6}$ Pulmonary resection is most common in the surgical treatment but has high morbidity and mortality. ${ }^{7}$ This serial case report is going to perform six patients with pulmonary fungus ball related Tuberculosis in term of diagnose methods, treatment and outcome.

\section{CASE}

We found six patients, 4 men and 2 women with range of age 35-61 years old. The main symptoms were hemoptysis and cough (Table 1). Three patients suffered from massive hemoptysis and the rest were not suitable for massive criteria, but they got recurrent hemoptysis. The right upper lobe was the most common location of fungus ball (Table 2). All radiologic findings both in plain chest radiograph and thoracic Ct scanning, there was typical appearance such crecentic sign. Fungal species confirmed by serologic examination in one patient, fungal culture in two patients and histopathology examination in two patients. Two patients undergo thoracic surgery (lobectomy). Others who ineligible for surgery, got antinfungal (Triazol): itrakonazol (2), flukonazol (1), flukonazol and itrakonazol (1). Antifungal given six month each, and three patients gave good response (Table 3). From clinical symptom there is nomore hemoptysis or bloody sputum in 6-12 months. From radiology, the pulmonary fungus ball is dissapear (Table 4).

Tabel 1. Present signs and symptoms of six patients with pulmonary fungus ball

\begin{tabular}{lcc}
\hline Characteristic & $\begin{array}{c}\text { Former } \\
\text { Tuberculosis }\end{array}$ & Tuberculosis \\
\hline Massive and & & \\
recurrent & 3 & - \\
hemoptysis & 3 & 1 \\
Recurrent & 4 & 1 \\
hemoptysis & - & - \\
Cough/Sputum & 1 & 1 \\
Dyspnea & & \\
Fever & & \\
\hline
\end{tabular}


Tabel 2. Location of pulmonary fungus ball of six patients with pulmonary fungus ball

\begin{tabular}{cc}
\hline Location & Number of patients \\
\hline Right upper lobe & 4 \\
Left upper lobe & 1 \\
Right upper and left upper lobe & 1 \\
\hline
\end{tabular}

Table 3. The diagnosis, etiology, therapy and outcome of six patients with pulmonary fungus ball

\begin{tabular}{|c|c|c|c|c|c|c|}
\hline \multirow[t]{2}{*}{ Patients } & \multirow{2}{*}{$\begin{array}{l}\text { Diagnosis } \\
\text { Method }\end{array}$} & \multirow[t]{2}{*}{ Species } & \multirow[t]{2}{*}{ Therapy } & \multicolumn{3}{|c|}{ Outcome } \\
\hline & & & & Hemoptysis & Radiology & $\begin{array}{c}\text { Free } \\
\text { hemoptysis } \\
\text { period } \\
\text { (month) }\end{array}$ \\
\hline 1 & Radiologically & & Flukonazole & No & $\begin{array}{c}\text { Decreasing in } \\
\text { volume* }^{*}\end{array}$ & 7 \\
\hline 2 & Fungal Serologic & Candida sp & $\begin{array}{c}\text { Flukonazole } \\
+ \text { Itrakonazole }\end{array}$ & Still occurred & Minimal decrease & - \\
\hline 3 & $\begin{array}{l}\text { Histopathology } \\
\text { examination }\end{array}$ & Aspergilosis & Lobectomy & No & Disappear & 10 \\
\hline 4 & $\begin{array}{l}\text { Histopathology } \\
\text { examination }\end{array}$ & Aspergilosis & Lobectomy & No & Disappear & 12 \\
\hline 5 & Fungal Culture & $\begin{array}{c}\text { Candida } \\
\text { parapsilosis }\end{array}$ & Itrakonazole & No & Disappear* & 12 \\
\hline 6 & Fungal Culture & Aspergilosis & Itrakonazole & No & Disappear* & 6 \\
\hline
\end{tabular}

\footnotetext{
${ }^{*}$ More than $50 \%$

** Empty cavity appearance
}

Table 4a. Radiologic findings pre and post therapy of six patients with pulmonary fungus ball

\begin{tabular}{lll}
\hline Patient & Pre & Post \\
\hline 1 & \\
2 & $R$ &
\end{tabular}


Table 4b. Radiologic findings pre and post therapy of six patients with pulmonary fungus ball

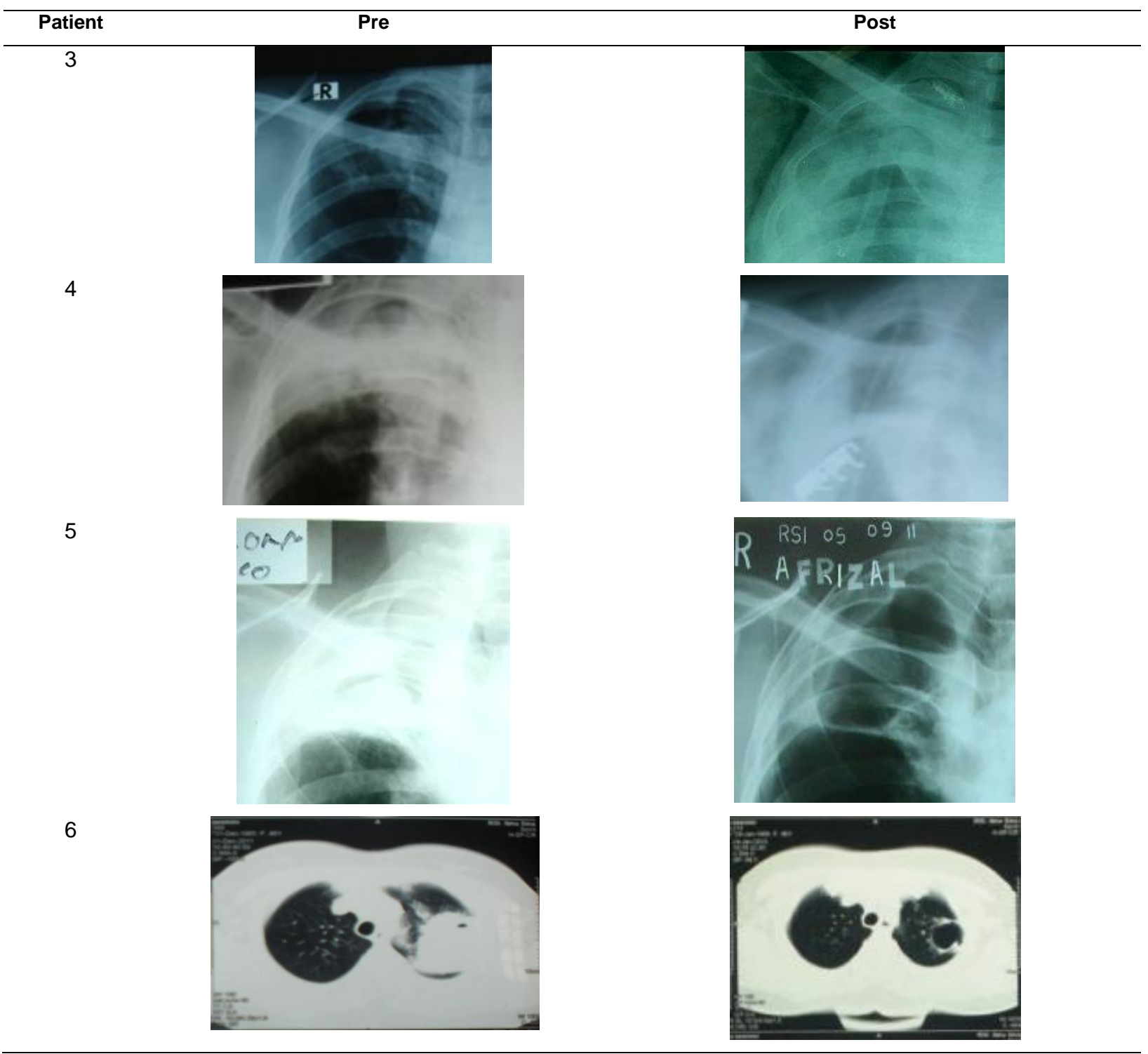

\section{DISCUSSIONS}

Fungal could colonized preexisting cavity originated variety underlying lung disease like tuberculosis, sarcoidesis, bronchiectasis and bronchogenic carcinoma. Fungal mix with cellular debris, fibrin and inflammatory cell formed a mass that called fungus ball. ${ }^{1}$ In this serial case we report six pulmonary fungus ball patients related to Tuberculosis, one in current tuberculosis and five as former tuberculosis. Tuberculosis has reported to be the most common underlying disease of pulmonary fungus ball $(60 \%)$. It has been reported that the most common symptom associated pulmonary fungus ball is hemoptysis. ${ }^{1,3,4}$ It is similar with our series. Three of our patients had massive and recurrent hemoptysis and the rest just recurrent hemoptysis. The cause of haemoptysis is neovascularization of the diseased segment from the internal mammary, intercostals and phrenic system of vessels. The pulmonary vascular system may also contribute to neovascularization. Other symptom that present in our series are chronic cough.

The apical portion of upper lobe especially right upper lobe were the common sites of disease in this series, which seem to reflect an association with pulmonary tuberculosis. Plain chest radiography is usefull in demonstrating the presence of a mass within a cavity. The lesions have been more frequently found in the upper lobes of the lungs, reflecting the predisposition of tuberculosis to cavitate in these areas A typical radiologic finding of pulmonary fungus ball is a solid, round or oval mass with soft-tissue opacity within a lung cavity, manifesting an "air crescent sign" 
without significant enhancement. ${ }^{1,2,4}$ In our series, all patients had typical radiograph appearance both in plain chest x-ray and thoracix CT scan.

Surgery has generally been considered to be mainstay of treatment for pulmonary fungus ball. The main indication for surgery is massive and recurrent hemoptysis. The major mode of therapy for pulmonary fungus ball has been surgical resection of the cavity and removal the fungus ball. Lobectomy is the most commonly employed procedure, although segmentectomy is sometimes adequate and pneumonectomy is occasionally required. Antifungal therapy is rarely considered as main treatment of pulmonary fungus ball. The main indication for medical therapy has been that the patient is not fit for surgical intervention or there is concern about concomitant tissue invation by the fungus. As in our series, only two patients underwent lobectomy and the patients had no longer hemoptysis. Four others couldn't perform surgical treatment because of the patient had poor lung function (1) and rejection (3). For those, we gave antifungal as the treatment; fluconazole and itraconazole. Itraconazole has been used with some reduction of size of the fungus ball and has been shown being well penetrate in to the lung cavity. ${ }^{8}$ Fluconazole is extensively used for the prevention and treatment of superficial and invasive Candida infections. ${ }^{9}$ In our series, two patients with itraconazole for six month showed no more hemoptysis and decreasing in volume of fungus ball that caused by from candida parapsilosis and aspergilosis radiologically. One patient respon with fluconazole for six months. Only one patient showed poor respon from itraconazole and fluconazole clinically and radiologically.

\section{CONCLUSION}

Preexisting cavity in pulmonary tuberculosis and former pulmonary tuberculosis, renounce the incident of pulmonary fungus ball which need lobectomy as definitive treatment. In condition where they can't perform surgical treatment, antifungal can be alternative treatment and gave good outcome. Antifungal may create the opportunity for patient that ineligible to perform surgical treatment. Nevertheless, larger number of patients and multicentre site still required to get more reasonable recommendation.

\section{REFERENCES}

1. Chamilos G, Kontoyoiannis DP. Aspergillosis, candida and other opportunistic mold infections of the lung. In: Fishman AP, Elias JA, Senior RM, Fishman JA, Kotloff RM, Pack Al. Fishman's Pulmonary Diseases and disorders Vol.2. $5^{\text {th }}$ ed. New York: MC Graw Hill; 2015. p.2039-69.

2. Jennifer L, Horan S. Opportunistic mycoses. In: Masson JR, Murray JF, Broaddus VC, Nadel JA, editors. Murray and Nadel's textbook of respiratory medicine. $6^{\text {th }}$ ed. Philadelphia: Elsevier; 2016. p.1010-47.

3. Taylor R, Dagenais T, Keller NP. Pathogenesis of aspergillus fumigatus in invasive aspergillosis. Clinical Microbiology Reviews. 2009; 22(3):447-65.

4. Behera D. Textbook of pulmonary medicine volume 1. $2^{\text {nd }}$ Edition. London: JP Medical Ltd; 2010. p.804-23.

5. Ravenel JG. Imaging of chest, heart, and great vessel. In: Chen MYM, Pope TL, Ott DJ, editors. Basic radiology. $2^{\text {nd }}$ ed. New York: The Mc Graw Hill Company; 2011. p.46-61

6. Perhimpunan Dokter Paru Indonesia. Mikosis paru. pedoman diagnosa dan penatalaksanaan di Indonesia. Jakarta: Perhimpunan Dokter Paru Indonesia; 2011.p.18-24

7. Limper $A H$, Knox KS, Sarosi GA, Ampel NM, Bennett JE, Catanzaro A, et al. An official American thoracic society statement: treatment of fungal infection in adult pulmonary and critical care patient. Am J Respir Crit Care Med. 2011; 183 (1): 96-128.

8. Gupta P, Jain J, Kewlaini J. A Comparative study of itraconazole in various dose schedules in treatment of pulmonary tuberculosis. Lung India Journal. 2015; 32(4):342-6.

9. Beed M, Sherman R, Holden S. Fungal infection and critically ill adults. British Journal of Anaesthesia. 2013;14(6):262-7. 